\title{
強ひずみ現象として見た転がり疲れによる 白色型組織変化
}

平岡 和彦*

White-type Microstructural Change in Rolling Contact Fatigue from the Viewpoint of Severe Plastic Deformation

Kazuhiko HiRAOKA

Synopsis : It is well known that three types of white-colored microstructural changes occure in rolling contact fatigue (RCF). Those are called WB (White band), Butterfly and WEA (White etching area) respectively. As the conditions of bearing use have become severer, recently these phenomena are observed more frequently. However, their formation mechanisms and countermeasures have not been clarified, because very complicated factors are involved in these phenomena. Authors remark the fact that white-colored microstructural changes consist of ultrafine grains. Although the formation of such ultrafine grains are generally found in SPD (Severe Plastic Deformation), it is expected that the knowledge in this field would be useful in the field of RCF, as well.

From this point of view, microstructural changes in RCF were reviewed in this report, referring previous studies and recent authors studies. Key words : rolling contact fatigue; microstructural change; WEA; Butterfly; ultrafine grains; nanocrystalline.

\section{1. 緒言}

近年, 地球環境保護のために自動車用をはじめとする各 種機械部品は, その小型・軽量化や新機構の採用が避けら れない状況にある。それに伴い軸受をはじめとする転動部 品は, その使用環境が過酷化され転がり疲れによる白色型 組織変が顕著に見られるようになっている。

白色型組織変化は, 光学顕微鏡における腐食組織の観察 にて白色を特徴として観察されるものであり, Fig. 1)に示 すように，マクロ的な形態が異なるWB (White band)型, バタフライ型ならびにWEA (White etching area)型の3つの タイプとして存在することが知られている。結果として早 期のはく離に関係して, 工業的な対策が強く望まれている ものはWEA型であることがわかってきている ${ }^{1)}$ が, 各々 は同じ白色を呈する組織変化であり依然として混乱され易
い。そもそも転がり疲れ自体が複雑な要因による現象で あって, 各々の組織変化の生成機構が系統的に説明される ことは困難であるとの見方がなされてきた。特にWEAは 一般の軸受として特異と見られる複数の環境下において生 じることが経験的に知られているので, 多くの従来研究は 環境を切口にしている。例えば, 水素 ${ }^{2)}$, 曲げ応力 ${ }^{3)}$, 振 動や衝撃荷重等 ${ }^{4,5}$ は挙げられてきた原因である。見掛け 上複数の環境要因により同じ組織変化が生じるので, 統一 的な説明に至り難いことには必然性があろうと考えられ る。

一方材料的な視点において, 3 タイプの白色型組織変化

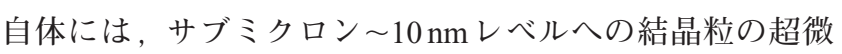
細化現象が起こっているという本質的な共通性を見出すこ とができ, 各研究者の報告内容にも矛盾がない。この事実 は各タイプの白色型組織変化の成因や生成機構にも本質的

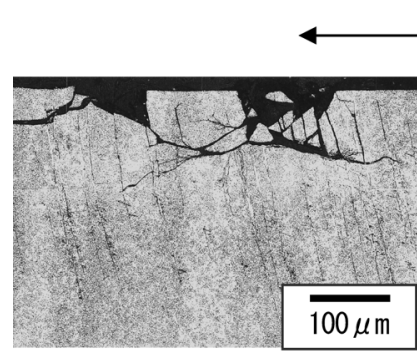

a) White band type (WB)

Ball moving direction

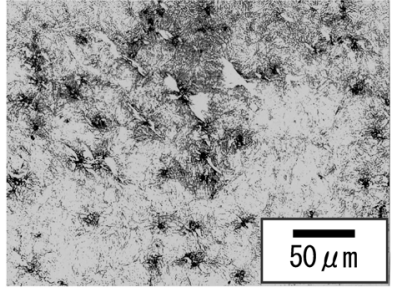

b) Butterfly type

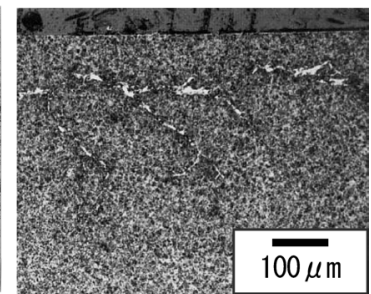

c) WEA

Fig. 1. Optical micrographs of White type microstructural changes in rolling contact fatigue. ${ }^{1)}$

平成 20 年 3 月 25 日受付 平成20年6月 4 日受理 (Received on Mar. 25, 2008; Accepted on June 4, 2008)

* 山陽特殊製鋼（株）研究・開発センター 軸受・構造用鋼グループ (Bearing \& Engineering Steel Groop, R \& D Center, Sanyo Special Steel Co., Ltd., 3007 Nakashima Shikama-ku Himeji 672-8677) 
な共通性が伴うことを示唆している。難解と見られがちな この問題の解決は，まずこの共通点に基くべきであろうと 考えられる。鉄鋼材料におけるサブミクロン以下への結晶 粒微細化は, $\mathrm{TMCP}$ 等の不連続再結晶や相変態による従来 型の微細化技術とは一線を画しており，強ひずみ加工によ る動的連続再結晶を伴う現象として，关の利用を目指して 知見が重ねられてきた分野である6。転がり疲れに打ける 白色型組織変化をそれらに準じたものとする見方 ${ }^{1,7}$ は， 問題の解決に向けた大きな手脚かりを生む可能性がある。

本報告では, 前半に転がり疲れの組織変化に関する従来 研究を主に材料の視点で整理した。結果として各組織変化 は塑性ひずみの局在化した蓄積現象に他ならず，その微細 化の到達レべルにおいて強ひずみ加工による種々の現象と 対比的な見方ができることがわかった。この見方による整 理は, 組織変化機構の解明に向けた研究課題を明確に示し ている。それは疲労の過程において何が塑性ひずみの蓄積 をもたらしているのかを見出すことであると言える。後半 には，この見方を基軸においた筆者らの機構解明に向けた 研究 ${ }^{1,8-10)}$ の概要を紹介する。

\section{2. 従来研究における組織変化観察結果の整理}

転がり疲れに打いて認められる3つのタイプの白色型組 織変化について, 前述の主旨に基いてマクロ的形態, 白色 部内部の特徵ならびに結晶粒微細化状態の詳細を従来研究 結果により整理した。

\section{$2 \cdot 1$ WBタイプ}

Fig. 1(a) ${ }^{1)}$ はJIS SUJ2焼入れ焼戻し材にて潤滑油温度 $423 \mathrm{~K}$, 接触面圧 $5.3 \mathrm{GPa}$ の高温高面圧でかつ良好な潤滑状 態でのスラスト試験により観察されたWBと，そこからの はく離状態を光学顕微鏡で観察した筆者による事例であ る。観察面は写真上側が軌道面であり軌道に平行である。 スラスト試験において WBは一般的に軌道面に対して約 $30^{\circ}$ と $80^{\circ}$ の角度にて観察されるが，Fig. 1(a)では主に $80^{\circ}$ バンドが軌道直下の広範囲に観察されている。またWBに は生成の起点が認められない。Fig. $2^{11}$ は Fig. 1(a) と同じ試 料にて軌道に対して垂直方向から観察した結果である。こ の場合はバンド状を示さず，深さ方向に向かって凸型形状 にて白色部が観察される。タイプの識別に打いて観察方向 への注意が必要である。Fig. $3^{11}$ は Fig. 1(a) と同じ試料を SEM観察した結果である。バンドの巾は約 $2 \mu \mathrm{m}$ であり， その内部はバンド伸展方向に沿った筋状模様を呈し炭化物 は消失しているかバンドの伸展方向にせん断変形されてい ることが観察されている。このWB内の炭化物消失現象は 筆者以外の報告内容 ${ }^{11)}$ も合致するものであり，後述する 他の白色型組織変化にも共通の現象である。Fig. $4^{11}$ は同じ 試料から薄膜試料を作成して TEM観察した結果である。 同図(a)の明視野像にて白く見える部分はWB部であると

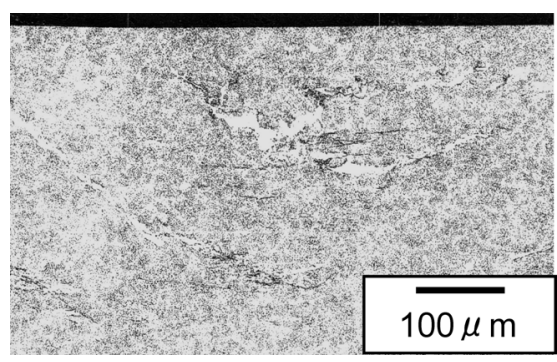

Fig. 2. WB observation vertical to the rolling direction. ${ }^{1)}$

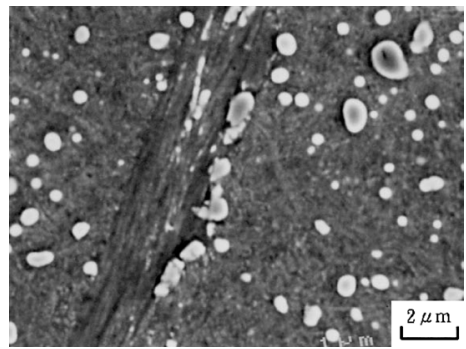

Fig. 3. SEM observation of WB. ${ }^{1)}$
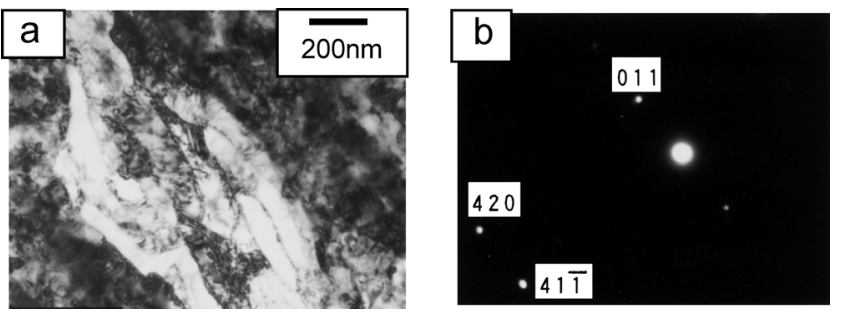

Fig. 4. TEM observation results of WB. ${ }^{1)}$ (a) Bright field image (b) Diffraction from WB area.

考えられるが，その内部は 100 200 nm 程度の若干バンド 長手方向に伸展したユニットを呈している。またユニット 間の境界部は不明瞭さを呈しており転位セル段階であると 見られる。同図(b)は転位セル内部の $100 \mathrm{~nm}$ の制限視野回 折像であり， $\alpha$ 構造のスポットパターンを呈している。 WBが初期結晶の微細化現象ではあるが，後述のバタフラ イやWEAが示す $10 \mathrm{~nm} レ$ ベルのナノ結晶化には至ってい ないことは明らかである。これらの結果は井口らの報告 ${ }^{12)}$ に合致し, 沖田ら ${ }^{13)}$ や植田ら ${ }^{14)}$ の WBが $10 \mathrm{~nm}$ レベルのナ ノ結晶ではなくWEA とは区別されるものとする報告にも 合致する。

\section{$2 \cdot 2$ バタフライタイプ}

Fig. 1(b) ${ }^{1)}$ は黒鉛を起点とするバタフライ生成の筆者に よる観察例である。観察面は写真上側が軌道面であり軌道 に平行である。バタフライは他の白色を呈する組織変化と は異なり，明らかに非金属介在物を起点とする特徵があり， き裂に沿った蝶の羽を思わせる白色タイプの組織変化であ る。P. C. Becker ${ }^{15)}$ はJIS SUJ2相当であるSAE52100を素材 とした玉軸受に生じたバタフライについて TEMを用いた 詳細な観察結果を報告している。バタフライは軌道面に対 して 40 45の傾きを持って非金属介在物を中心に，その 
両サイドにき裂を伴った白色の羽部を呈すること, 白色部 には光学顕微鏡観察では炭化物消失現象が認められるこ と，さらに白色部が $10 \mathrm{~nm}$ 程度の $\alpha$ 構造超微細結晶粒であ り，さらに光学顕微鏡では認められない炭化物が TEMで は $7 \mathrm{~nm}$ 程度のセメンタイトとして分散していることを報 告している。井口ら ${ }^{12)}$ も同様にバタフライの白色部が $10 \mathrm{~nm}$ 程度のナノ結晶粒からなることを報告している。

\section{$2 \cdot 3$ WEA タイプ}

Fig. 1(c) $)^{1)}$ にJIS SUJ2製玉軸受軌道輪に生じたWEAの軌 道平行断面の光学顕微鏡による筆者の観察例を示す。WB と同様に軌道直下の広範囲に観察されるが, バンド状では なく不規則形状を呈しながら軌道直下 $0.1 \mathrm{~mm}$ 深さあたり を頂点として深さ方向へ枝垂れ柳状を呈する形態にて観察 される。同じ試料をSEM観察した結果を Fig. $5^{11} に$ 示す。 内部の筋状模様や炭化物消失等，WB や゙タフライ内部の 特徵と同じである。また同図においてWEAはき裂と共存 しているように見受けられる。WEAについての報告例は， 前述のように主に環境を切口とした特異現象として紹介さ れており, 統一的な生成原因を見出せないのであるが, 直 近の報告 ${ }^{16-18)}$ では，鋼中に浸入する水素が関与しているこ とが明確に示されてきた。WEAの生成起因として挙げら れてきた各種環境要因は，何らかの形で水素との関連があ るものと推測される。しかしながら材料視点の観察結果で あるWEAが $10 \mathrm{~nm}$ レベルの超微細粒に至っているという 点については複数の報告があり矛盾はない ${ }^{4,13,14,19) 。 こ の ~}$ 点においてWEAはバタフライとマクロ的形態を異にする が，材料的に見た内部構造は同質のものであるという見方 が可能である。

\section{$2 \cdot 4$ 従来研究の総括}

転がり疲れに打ける3つのタイプの組織変化は, 全て初 期結晶粒の超微細化現象であって，WBで 100 200 nmの 転位セル段階（もしくは結晶），バタフライとWEAが $10 \mathrm{~nm}$ 程度のナノ結晶であるという矛盾のない特徴が見出 せた。一方, 強ひずみ加工研究において ECAPやARBに 代表されるバルク全体の加工手法では微細化の到達が $100 \mathrm{~nm}$ レ゙ルであり，主に材料表面の加工により付与さ れる応力の複雑化が見込まれるボールミルやショットピー

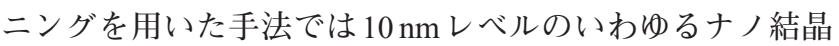
が得られるという概念が知られている ${ }^{6,7)}$ 。前者が転がり 疲れのWBに，後者がバタフライやWEAに相当するとい う対比的な見方が可能である。

また白色部内部の特徴として，炭化物がせん断されたり 消失したりする現象や, 塑性流動を思わせる筋状の模様が 確認されていること，さらにWBにおいて転位セル状態が 観察されており，なおかつそれらが等軸ではなく伸長して いる点等は加工起因としての性格を強く帯びているもので ある。これらの現象は, 白色型組織変化が強ひずみ加工に よる現象と材料の視点では等価なものとして見てよいこと

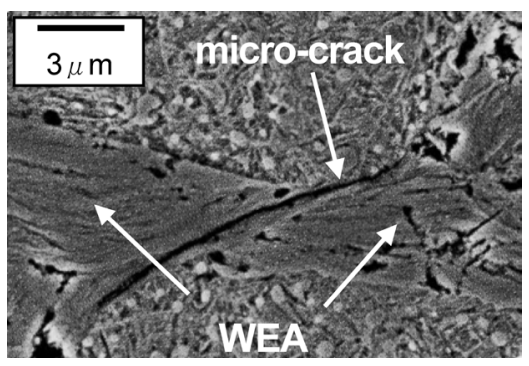

Fig. 5. SEM observation of WEA. ${ }^{1)}$

を確実なものにしている。

\section{3. 筆者らの研究概要}

前述のように，実用的には各種組織変化の中でWEA生 成とそれを伴う早期はく離の機構解明が重視される。筆者 らは最終的にその解明を目指して, 二段のステップにて研 究を進めてきた。いずれの研究も, 前述の主旨により局所 塑性がキーであるとの見方を基にしているが，さらに疲労 の基本的な過程（初期き裂生成 $\rightarrow$ 伝ぱ $\rightarrow$ 破壊）において, それがどのように発現するのかの見極めを意識して実験や 観察方法の考案を行っている。なぜならば組織変化自体の 生成機構解明だけではなく, 最終的には疲労破壊としての 対策につながる知見を見出す必要があるからである。

第一の研究 $(3 \cdot 1$ 節 $)$ は人工欠陷導入試料を用いたバタ フライ型組織変化の再現である ${ }^{1,8,9)}$ 。前述のようにバタフ ライはWEAと材料的に見て同質であり，生成機構におい て何らかの共通性があることが示唆されている。ここでは 明確な起点を持ち, 規則的な形態を呈するバタフライに解 析の容易さを期待して研究対象として先行させた。

第二の実験 $\left(3 \cdot 2\right.$ 節) は, 従来研究 ${ }^{2,20)}$ に倣った水素

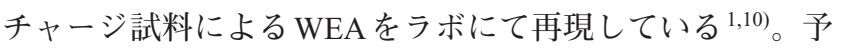
想通りにWEA形成にはバタフライとの本質的な共通性が 見出されており, 両者の対比による機構究明を進めた。

\section{$3 \cdot 1$ バタフライの再現実験 $1,8,9)$}

バタフライが一般的に非金属介在物を起点として生じて いる事実 ${ }^{1)}$ や，筆者らが以前に黒鉛鋼中の黒鉛を起点とし たバタフライ再現に成功している経緯 ${ }^{21)}$ を踏まえ，軸受鋼 中に応力集中源として人工空洞欠陷を導入した供試材を考 案した。昨今の軸受鋼中には非金属介在物の存在頻度が極 めて低く, 偶発的なバタフライ生成の観察では, 経時的な 見方や多数の結果を踏まえた解析が行えないという問題が あり，考案した試料はその解消を狙ったものである。

試験片は，ガスアトマイズ粉末を原料としたHIP 固化に よるJIS SUJ2相当組成のバルクであるが, HIP 条件の選定 によって意図的に数〜数十 $\mu \mathrm{m}$ の空洞を内包させている。 さらに一般的な軸受鋼に付与される焼入れ焼戻しにて硬さ 62HRCに調整して仕上げた。転がり疲れ試験は，接触面 


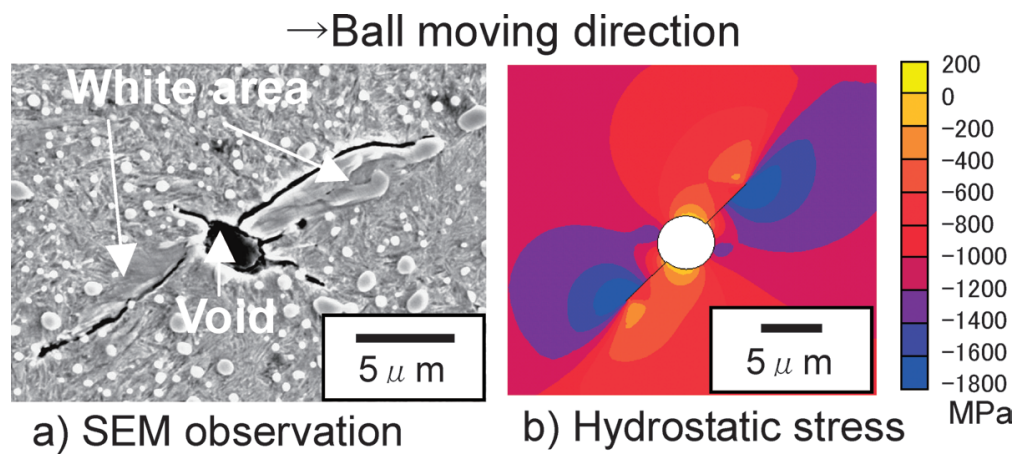

Fig. 6. Comparison of observed Butterfly and stress analysis result. ${ }^{1)}$

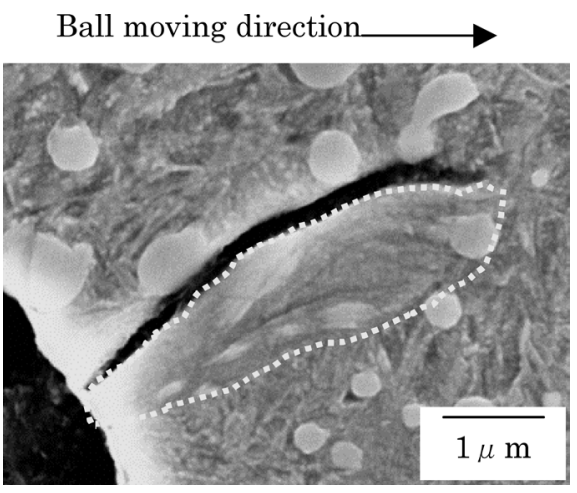

Fig. 7. SEM observation of White area generated around void. ${ }^{9)}$ Cycles: $5.0 \times 10^{5}$, depth: $70 \mu \mathrm{m}$.

圧 $P_{\text {max }}=3.92 \mathrm{GPa}$ の常温潤滑によるスラスト型にて実施し た。この実験により得られた主な結果を以下に示す。

(1) $1 \times 10^{4}$ サイクル時点で空洞を起点としてその両サ イドに初期き裂が生じる。その形成には規則的な方向性が あり，軌道に対して概ね $45^{\circ}$ 以下の角度である。なおこの 時点では白色部 (羽部) は観察されない。

（2）この初期き裂は, 筆者らの後の研究における破面 の性状，角度ならびに生成深さの検証により，空洞周囲の 引張主応力（Mode I 型）によるものと推定された ${ }^{22)}$ 。さら に初期き裂生成の前段階として空洞周囲の応力集中による 塑性領域の存在があること ${ }^{23)} も$ 確認している。

（3） $1 \times 10^{5}$ サイクル以降に初期き裂に沿って白色部が 出現する。その生成部位は Fig. 6(a $)^{1)}$ に示すように幾何学 的な規則性があり，空洞からみた転動体移動方向に対する 前方き裂の下側と後方き裂の上側 2 ヶ所に限られる。なお 白色部はSEMにおいては，白色ではなくマルテンサイト 特有の針状組織が消失した平滑部として観察されるので， その識別が可能である。

（4）白色部の内部は Fig. $7^{99}$ に示すように筋状模様を有 しており，それらの伸展方向は主せん断方向に合致するこ とをFEM応力解析にて確認している ${ }^{9}$ 。同困において白色 内部の炭化物は筋状方向に沿って变形を受けており，消失 する途上にあると見られる。また白色部の生成はき裂先端 までに止まり，白色部が単独で進展していることは見受け

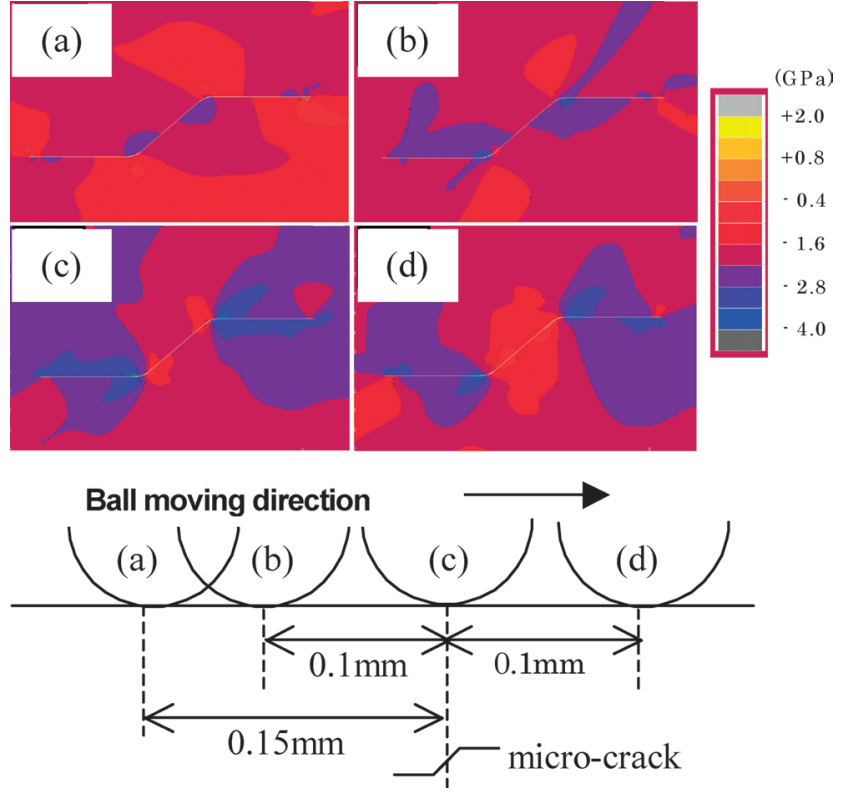

Fig. 14. Hydrostatic stress distributions around microcrack at various ball positions. ${ }^{10)}$

られない。

（5）白色部はFig. $8^{9}$ に示すTEM観察結果により, 従 来知見通りに $10 \mathrm{~nm}$ 程度のナノ結晶であることが明らかで ある。

以上の結果の中で, 白色部がき裂に対して規則的な生成 位置を示す事実は，き裂の幾何学的な効果による特定の応 力状態が白色部形成に関与していることを強く示唆するも のである。単にき裂面の摩擦やそれによる昇温が主要因で ある現象であればこの事実は有り得ないからである。考察 のために実験モデルの FEM応力解析を試みた結果, Fig. 6 b） ${ }^{1)}$ に示すように白色部は静水応力分布において他部位と 比べて圧縮応力が高い部位であることがわかった。なお計 算は実験結果を模し, 直径 $5 \mu \mathrm{m}$ の空洞が最大せん断応力 位置（軌道直下 $0.12 \mathrm{~mm}$ ）にあり，その両側に初期き裂が 各々 $5 \mu \mathrm{m}$ の長さならびに軌道に対して $45^{\circ}$ 方向にて予め存 在するという前提で, 転動体を移動させて動的に実施して いる。同困の結果は転動体が空洞の真上にきた時点のもの ある。また局所的な塑性による現象であるとの見方から塑 


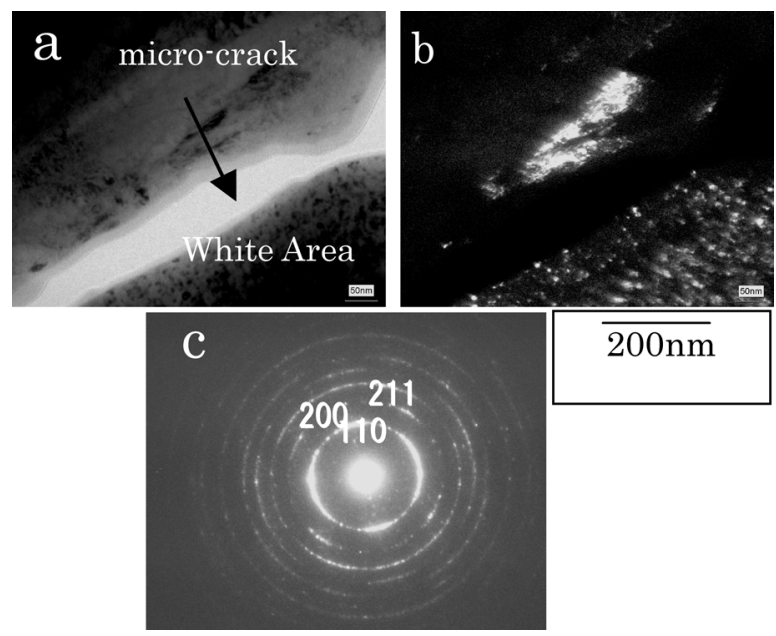

Fig. 8. TEM observation results. ${ }^{9)}$ (a) Bright field image, (b) dark field image, (c) diffraction from White area.

性への関与が大きい相当応力ならびに偏差応力分布との関 係も調べたが, バタフライのマクロ的形態を示す結果は見 出せなかった。単に降伏により塑性が生じやすい部位が， 白色化すなわちナノ結晶化を示すわけではないことは明確 であった。応力解析結果と組織変化形成との関係について は次章にて考察する。

\section{$3 \cdot 2$ WEAの再現実験 1,10$)$}

JIS SUJ2の通常焼入れ焼戻し材を試験片に用い，323K の $20 \%$ チアシオン酸アンモニウム溶液へ $172.8 \mathrm{ks}$ 浸漬して 水素チャージを行った。試験片の水素含有量は昇温脱理法 (TDS 法) ${ }^{24)}$ による室温 573K までの放出量で $1.3 \mathrm{ppm}$ で あった。水素チャージ後, 直ちに接触面圧 $P_{\text {max }}=5.29 \mathrm{GPa}$ の常温潤滑によるスラスト型転がり疲れ試験を実施した。 以下に主要な結果を示す。

(1) 水素チャージ材のはく離寿命は, Fig. $9^{10)}$ に示す ように $\mathrm{L}_{50}$ 寿命において非チャージ材の約 $1 / 3$ であった。

(2) $1 \times 10^{5}$ サイクルにて Fig. $10^{100}$ に示すように軌道直 下の随所に長さ $5 \mu \mathrm{m}$ 程度の概ね地の針状組織に沿った初 期き裂が観察された。

(3) $1 \times 10^{6}$ サイクル以降にWEAが出現することを確認 した。Fig. $11^{10)}$ に $1 \times 10^{6}$ サイクル時点の観察結果を示す。 この時点では引続き針状を呈する初期き裂（同図(a))，な らびにそれらが主に至近距離のもの同士連結して形成した と見られるき裂（同図(b)）が観察され，WEAは主として 同図(c)に見られるようにき裂のキンク部内側に生じてい ることがわかった。同図(d) は他の観察結果が軌道に平行 な断面のものであるのに対して, 軌道に垂直な断面での観 察結果である。針状ではなくさらに短いき裂，もしくはボ イド状の隙間が観察されていることから, 軌道に平行な断 面にて針状に観察された初期き裂は3次元的にも針状であ る可能性が高いと見られる。

(4) Fig.12(a) ${ }^{1)}$ に $8.6 \times 10^{6}$ サイクル時点の軌道平行断面

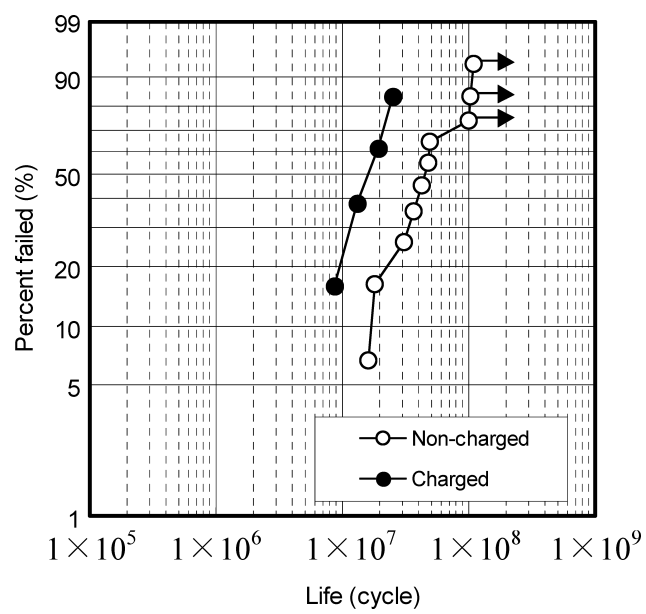

Fig. 9. Results of rolling contact fatigue test. ${ }^{10)}$

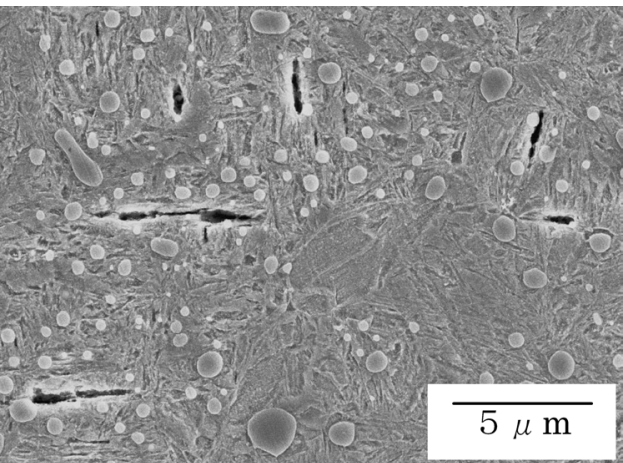

Fig. 10. SEM microstructural observation of hydrogenchaged specimen at $1 \times 10^{5}$ cycles. $^{10)}$
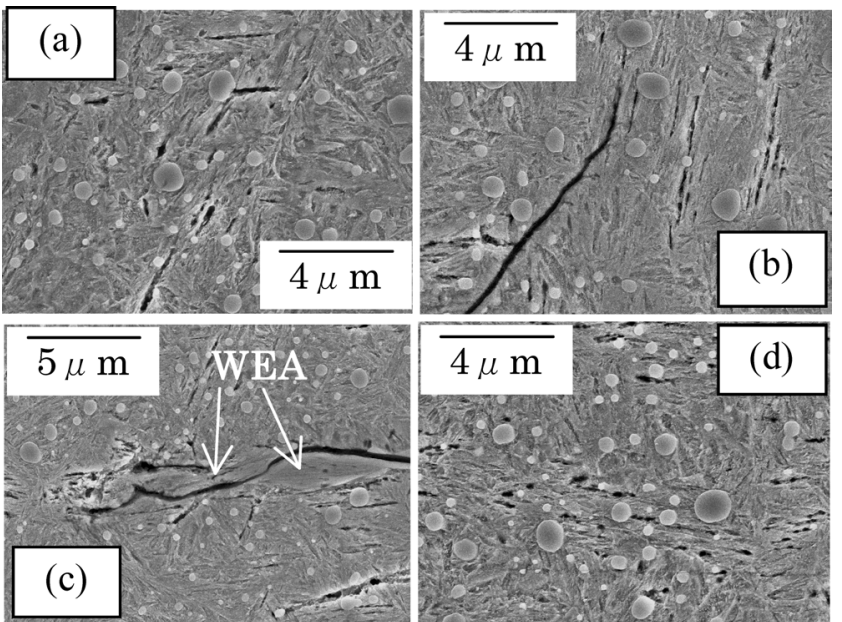

(c)

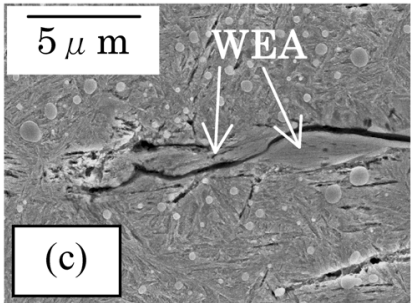

Fig. 11. SEM microstructural observation of hydrogenchaged specimen at $1 \times 10^{6}$ cycles. $^{10)}$

の光学顕微鏡組織を示す。当試験片ははく離に到っており， はく離底の深さは $100 \mu \mathrm{m}$ 程度である。またはく離底は軌 道方向に $150 \mu \mathrm{m}$ 程度の水平部を有しており, 内部起点で ある前提に立てば，その水平部から表面に伝ぱしてはく 離に至ったと判断される。一方組織変化は, 主に 100 150 $\mu \mathrm{m}$ 深さにて水平に黒色帯として伸展しており， 部分的に $300 \mu \mathrm{m}$ 程度の深さまで進展している。白色部す 

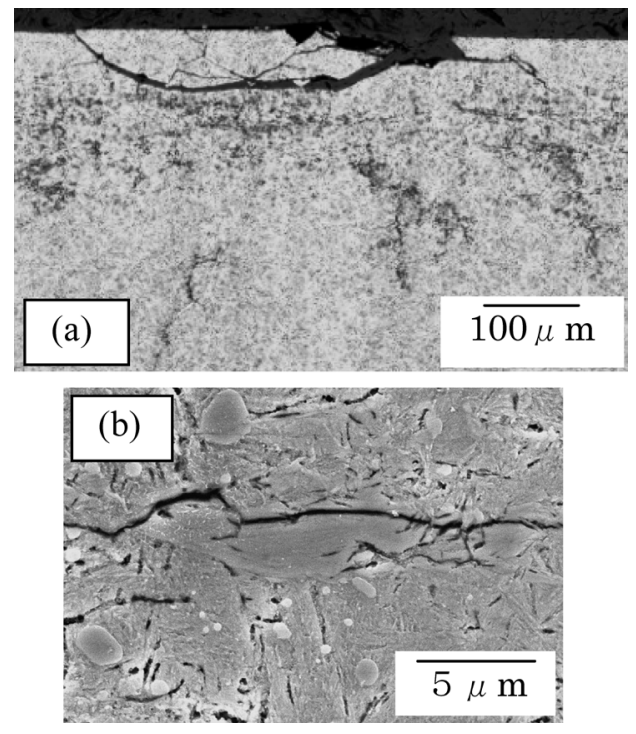

Fig. 12. Microstructural observation of hydrogen-chaged specimen with flaking at $8.6 \times 10^{6}$ cycles. ${ }^{1)}$ (a) Optical observation, (b) SEM observation

なわちWEAは黒色帯の中の一部に観察されている。

( 5 ） Fig.12(b) ${ }^{1)}$ はFig.12(a) ${ }^{1)}$ における深さ $170 \mu \mathrm{m}$ 位置の 黒色帯をSEMにて拡大観察した結果である。その内部は 針状を呈する初期き裂，それらが連結したと見られるキン クを呈するき裂ならびにその一部に生じた WEAが認めら れる。

以上のWEA再現実験において，針状を呈する特徵的な 初期き裂が見出されている。筆者以外の従来研究において もWEAの先駆状態として針状を呈する組織が出現するこ とは指摘されている。前田ら ${ }^{2)}$ は水素チャージによる実験 で「black needle内部のき裂」として報告し，原田ら ${ }^{25,26)}$ は 転がりすべり接触環境による実験で「針状組織」として指 摘している。さらに原田らは針状組織をFIBにより断面現 出してSIM観察を実施しており，観察断面上で凹みである との表現を採っている。これらは筆者らの指摘する針状を 呈する初期き裂と大きさならびに形態的特徴から判断して 同じものであると考えられる。な筆者らが初期き裂とし て認めたものが化学的な腐食による隙間であるという可能 性も否定できないので，アルゴンイオンによるフラットミ リングにて表面を仕上げて観察した結果, Fig.13 ${ }^{27)} に$ 示す ように明らかにき裂であることが確認できた。

またこの初期き裂は, 軌道直下の随所に分散しており， その特徴から至近距離同士の連結により早期に大型化のき 裂と化し，それらを予き裂として早期はく離を起こしてい るものと見られる。したがって推定された早期はく離の過 程においてWEAは直接的には関与していないことがわか る。それらはき裂に沿った一部分に生じており，主にキン クの内側に存在している。この特徴は, 前述のバタフライ と類似しており，WEAの存在位置もき裂の幾何学的な特 徴の影響を受けていることが示唆された。バタフライでの

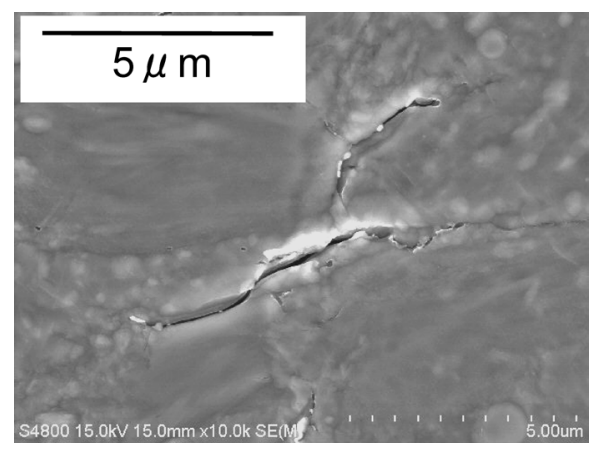

Fig. 13. SEM microstructural observation of Needle-likecrack at $1 \times 10^{5}$ cycles which was finished by $\mathrm{Ar}$ ion Flat-milling. ${ }^{27}$

検証と同様に応力解析を実施した結果，き裂のキンク部内 側はFig. $14^{10)}$ に示すように転動体の移動に対して概ね静水 応力分布において圧縮応力が高い状態で推移することがわ かった。この傾向はバタフライ羽部 (白色部) の生成位置 が示した傾向と合致するものであった。

\section{4. 白色型組織変化生成に関する考察}

従来研究知見の整理ならびに筆者らの研究結果により, 転がり疲れに打ける3つのタイプの白色型組織変化は何れ も塑性ひずみの蓄積した現象であると断定できよう。以下 に3タイプの組織変化についてその生成機構ならびにはく 離との関係を考察する。

\section{$4 \cdot 1$ バタフライ生成に関する考察}

バタフライは転がり疲れにおいて, 非金属介在物（本報 告の実験では空洞）を起点として生じる初期き裂生成に起 因する現象である。白色を呈する羽部は, 塑性ひずみの蓄 積によりナノ結晶化が起こっており，そのマクロ的な形態 は, 初期き裂の幾何学的効果によって説明される。羽部形 成の位置は結果として降伏を起こしているのであるが, 静 水圧縮応力が周囲に比べて高い位置であって, 相当応力や 偏差応力の高さでは説明されない。転動体の接触による全 体的な圧縮場において静水圧縮応力がより高い部分は, 新 たなき裂生成や伝ぱを起こし難い効果があると同時に，塑 性寄与応力成分である偏差応力が小さい比較的等方的な応 力場であると言える。この作用により塑性領域を局所的に 止めて, 繰返し応力により塑性ひずみを漸増させる効果を 得て, 強ひずみ加工に準じたナノ結晶化に至ったものと推 定する。すなわち白色型組織変化部の形成には降伏だけで はなく, 局所的に塑性ひずみを蓄積させる条件が伴う必要 があるものと解される。また初期き裂は, 筆者らのその後

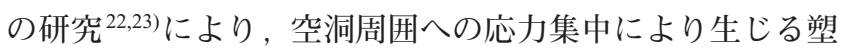
性領域に扎いて引張の主応力 (Mode I)により引き起されて いることがわかっている。この見方から, 非金属介在物か らの初期き裂は白色には至らないが局所塑性による広義の 組織変化が関与しているとも言えよう。なお筆者らの研究 
における実験は, 非金属介在物ではなく空洞を起点として いるが，実際の非金属介在物においても母相との界面はく 離があることを想定して ${ }^{22)}$ ，同様の初期き裂形成ならびに 白色部形成メカニズムによってバタフライは形成されるも のと推定している。Nèlias ${ }^{28)}$ は筆者らの研究とほぼ同じ 条件下の転がり疲れ試験によって, 筆者らの指摘とほぼ同 じサイクルである全寿命の極初期に，実際の非金属介在物 からき裂を伴うバタフライ生成があることを報告してい る。このようなバタフライ生成の機構は, 非金属介在物起 点の初期き裂形成の過程を説明しており，非金属介在物制 御による長寿命化への重要な指針を与えている ${ }^{29)}$

\section{$4 \cdot 2$ WEA生成に関する考察}

WEA生成を伴う早期はく離は, 水素によって引起され る軌道直下随所に出現する針状を呈する初期き裂が，早期 に連結して大型の予き裂を形成するために生じるものと推 定された。筆者らの実験においてWEA型はく離の寿命は 通常（非水素チャージ材）の短寿命のものと大差がなく (Fig. 9), 両者が内部起点型はく離として乘離していない結 果になっていることもその推定を裏付けるものである。一 方当初の着眼点であるWEA自体は大型の予き裂に沿った 一部に生じており，疲労過程としては二次的な現象である と言え，バタフライと同じくき裂形状の幾何学的効果によ りもたらされる塑性ひずみの局所的な蓄積によるナノ結晶 化現象である。ここで注目されるべきは水素と初期き裂生

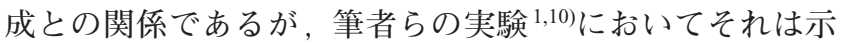
すことができていない。しかしながら水素と疲労との関係 に関して, 宇山ら ${ }^{30)}$ がすべりの局在化, すなわち微視的な 塑性変形の局在化を鋼中水素がもたらすことを報告してい る。この報告を考え合わせればWEA型の初期き裂が水素 による微視的塑性変形の局在化によりもたらされていると いうモデルを推定として挙げることができる。筆者らの研 究におけるSEM と光学顕微鏡を主体とする組織観察では, 初期き裂近傍に白色を呈する組織変化は認められていない が，これは塑性ひずみの蓄積が光学顕微鏡観察で白色を呈 するWEAと比べて小さいためであると解釈される。初期 き裂生成以前に, 転位セル化や局所的な微結晶化は進行し ているものと推定される。これはバタフライ生成の過程に おいて初期き裂形成以前にも非金属介在物周囲への応力集 中による塑性領域形成があること ${ }^{23)}$ と概念的に共通する。 すなわちバタフライとWEAは材料的に見て同質のもので あるが，各々の初期き裂形成過程の違いによって，異なっ たマクロ的形態を呈することが説明される。前者が非金属 介在物への物理的な応力集中に，後者が水素の作用による 軌道直下随所への塑性領域形成に端を発することによるの である。

\section{4·3 WB（ホワイトバンド）生成に関する考察}

WBは, 形成過程や結果としての結晶粒の微細化程度に おいて, バタフライやWEAとは本質的に異なる。起点や
先行するき裂を伴わない軌道直下の広範囲な塑性による変

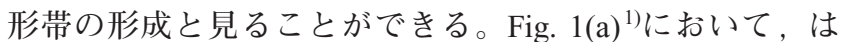
く離に至るき裂は，母相とWBとの界面から生成している ように見受けられる。このような原因から高面圧であるラ ボでの加速試験や高温環境に限られた現象であることが解 釈される。実用上は高温環境軸受に見られる現象であるが， 三田村ら ${ }^{31)}$ により焼戻し軟化抵抗を上げる方向の実践的な 材料・熱処理対応策が既に示されている。

\section{5. 結言}

一連の検討において，転がり疲れにおいて白色を呈する 組織変化であるWB，バタフライならびにWEAは局所的 な塑性ひずみの蓄積であり, 強ひずみ加工での結晶粒超微 細化現象と等価な現象であることが明らかに示された。こ の見方を前提として, 転がり疲れの過程において何が塑性 ひずみの蓄積をもたらすのかに着眼した筆者らの研究によ り, 各組織変化のマクロ的な形成過程が説明できている。 WEA は工業的に見て早期はく離に関与し，特にその対策 が強く求められるものであるが, 水素を原因とした特徽的 な初期き裂生成が見出された。その材料対策は初期き裂の 頻度ならびに長さの軽減を介した大型予き裂化の防止に他 ならず，考察された初期き裂形成機構から微視的な塑性に 対する抵抗を増すことであると結論される ${ }^{32)}$ 。

\section{文献}

1 ) K.Hiraoka: CAMP-ISIJ, 20 (2007), 424.

2 ) K.Maeda, H.Nakashima and N.Tsushima: Proc. of the Japan Int. Tribology Conf., Nagoya, (1990), 791.

3 ) Y.Murakami, H.Takemura, M.Naka, T.Ogawa, T.Ogawa, T.Momono, A.Iwahara, and S.Ishihara: NSK Tech. J., 656 (1993), 1.

4 ) M.Shibata, M.Gotoh, and T.Mikami: Proc. of the Japan Int. Tribology Conf. Yokohama, (1995), 1351.

5 ) K.Azuma: Fujikoshi-giho, 55 (1999), 48.

6 ) N.Tsuji: Tetsu-to-Hagané, 88 (2002), 359

7 ) M.Umemoto: Sanyo Tech. Rep., 11 (2004), 13.

8 ) K.Hiraoka, M.Nagao and T.Isomoto: J. ASTM Int., 3 (2006), No. 5, Paper ID JAI14059.

$9)$ K.Hiraoka, M.Nagao, H.Tsubakino and A.Yamamoto: J. Jpn. Soc. Tribol., 51 (2006), 744.

10) K.Hiraoka, T.Fijimatsu, N.Tsunekage and A.Yamamoto: J. Jpn. Soc. Tribol., 52 (2007), 888.

11) H.Swahn, P.C.Becker and O.Vingosbo: Mat. Sci., (1976), January, 35.

12) M.Iguchi and K.Tsubota: CAMP-ISIJ, 10 (1997), 545.

13) S.Okita, H.Takemura and Y.Murakami: CAMP-ISIJ, 12 (1999), 351.

14) K.Ueda, N.Mitamura, Y.Murakami and M.Ohori: CAMP-ISIJ, 15 (2002), 1033.

15) P.C.Becker: Met. Technol., (1981), June, 234.

16）宇山英幸, 飛鷹秀幸, 藤田慎治, 山田紜樹, 三田村宣晶：卜 ライボロジー会議予稿集，佐賀，(2007），53.

17）原田 久：トライボロジー会議予稿集，佐賀，(2007）， 55.

18）川村隆之, 三上英信：トライボロジー会議予稿集, 佐賀, (2007) , 57.

19) A.Muroga and H.Saka: Tetsu-to-Hagané, 84 (1998), 351.

20) N.Kino and K.Otani: CAMP-ISIJ, 15 (2002), 1016.

21) H.Kinoshita and K.Hiraoka: Proc. of the Int. Tribol. Conf., Nagasaki, (2000), 1719

22) T.Fujimatsu, K.Hiraoka and A.Yamamoto: Tetsu-to-Hagané, 94, 
(2008), 13.

23) K.Hiraoka, T.Fujimatsu, K.Hashimoto, S.Fukumoto and A.Yamamoto: Mat. Sci. Forum, 561-565 (2007), 2151.

24) K.Takai: Trans. Jpn Soc. Mech. Eng., 70 (2004), 1027.

25) H.Hadada, N.Oguma, A.Tamamoto and H.Tsubakino: Tetsu-toHagané, 89 (2003), 789.

26) H.Hadada, T.Mikami, A.Tamamoto and H.Tsubakino: Tetsu-toHagané, 91 (2005), 567.

27) 平岡和彦：兵庫県立大学工学博士論文, (2008), 90 .
28) D.Nèlias, M.L.Dumont, F.Champiot, A.Vincent, D.Girodin, R.fougères and L.Flamand: Trans. ASME J. Tribol., 121 (1999), 240.

29) 平岡和彦：兵庫県立大学工学博士論文, (2008), 21。

30) H.Uyama, Y.Mine, Y.Murakami, M.Nakashima and K.Morisige: $J$. Soc. Mat. Sci. Jpn., 54 (2005), 1225.

31) N.Mitamura, K.Seki and Y.Murakami: NSK Tech. J., (1994), No. 658, 11

32) 平岡和彦：兵庫県立大学工学博士論文, (2008), 104. 